Mentel, G., Brożyna, J., \& Szetela, B. (2017). Evaluation of the effectiveness of investment fund deposits in Poland in a time of crisis. Journal of International

Studies, 10(2), 46-60. doi:10.14254/2071-8330.2017/10-2/3

\title{
Evaluation of the effectiveness of investment fund deposits in Poland in a time of crisis
}

\section{Grzegorz Mentel}

Rzeszow University of Technology,

Rzeszow, Poland

Email:gmentel@prr.edu.pl

\section{Jacek Brożyna}

Rzeszow University of Technology,

Rzeszow, Poland

Email:jacek.brozyna@prz.edu.pl

\section{Beata Szetela}

Rzeszow University of Technology,

Rzeszow, Poland

Email:beata@prz.edu.pl

Abstract. The present publication constitutes an attempt at evaluation of the effectiveness of investment fund deposits at Polish market in the years 20002015. In the paper, a distinction is made between two subperiods, namely, the years before the economic crisis, meaning 2000-2006, and the years of the socalled crisis, meaning 2007-2015. This approach had the goal mainly of evaluating the effectiveness of investment fund deposits in the years of economic slowdown. Conclusions concerning the investment funds are based on a broad range of coefficients and measures used in literature on the subject matter. The multitude of quantitative evaluation criteria of investment funds taken into account in the publication should enable a more precise evaluation of the discussed issue. At the same time, besides the temporal subdivision mentioned above, the authors consider it important to confirm or deny any possible rules or similarities in the indications of the discussed measures. Grouping of the investment funds based on investment effectiveness can be a further advantage.

Keywords: investment funds, efficiency, investing, risk, financial market.

JEL Classification: C01, C58, G32

\section{INTRODUCTION AND REVIEW OF RESEARCH}

According to their definition, investment funds constitute a certain form of common investing entailing in principle joint depositing of financial resources, paid up by the participants in a given fund. 
Accordingly, thanks to this group approach to resource allocation, they are commonly considered to be one of the most successful and effective financial innovations. They can be found almost at all markets worldwide, in which they either play the role of a grand economic force, or a minor financial institution of marginal importance (Khorana, Servaes, \& Tufano, 2005). They permit one to shift the responsibility and the risk for the transferred resources to those managing the relevant fund. In addition, they permit the execution of financial investments also by those, whose knowledge about financial markets is to a certain extent limited, or by those who are not able to take the risk that we face every day when investing financial resources in the diverse available instruments.

Interest in investment funds among average investors stems mainly from the conviction that one's money is bestowed upon professionals. In addition, bank deposits and savings accounts do not provide returns at a level expected by clients. It thus seems that these are the key determining factors of the continued appeal of such institutions.

It certainly needs to be noted that funds, as any other investment option, do carry a certain degree of risk. Their decisive advantage is, however, the very broad flexibility and diversity, thanks to which funds can be chosen to suit one's investment portfolio so as to retain the necessary balance. In addition, long-term investments allow valuations to be averaged out and singular losses in a time of economic downturn to be limited.

Selection of a fund translates into the risk to be obtained, precisely in correlation to the investment horizon. In case of stock-based funds, considered the most risky, the short horizon may, in a disadvantageous time, bring results that are the opposite of what one would expect. However, mixedportfolio funds permit one reduce possible losses. It should be remembered, however, that there exists an entire range of safe funds, where the risk is minimal. They invest their resources in such instruments as bonds or treasury securities.

Keeping in mind the provisions and remarks detailed above, it would be worthwhile to attempt to measure the effectiveness of investment funds. In this regard, it is the fundamental goal of the present study to attempt an evaluation of Polish investment fund market considering the effectiveness indicators. An additional advantage of the present deliberations is the division of the study into the period before the crisis, and the period spanning the crisis.

The multitude of quantitative evaluation criteria of investment funds taken into account in the publication should enable a more precise evaluation of the discussed issue. Thus, beside the above delineated temporal subdivision, aiming a possible evaluation of the influence of economic turmoil, like the crisis, on the fund sector, for the authors it was also important to confirm or exclude possible rules or similarities in the indications of the discussed measures. In addition, an attempt was made to group the funds according to the investment effectiveness level.

\section{LITERATURE REVIEW}

During a review of the literature concerning investment funds by various authors, it is worthwhile to devote one's time to the publication by K. Perez (Perez, 2012). In this paper, a broad analysis war carried out of issues related to the investment fund market, both in terms of developed markets, as well as in Poland. Z. Wilmowska and M. Madera (2001) and D. Witkowska (2009) also focus their attention on the Polish investment fundmarket. T. Miziołek, who in the years 1998-2008 had published a range of interesting articles in the journal Nasz Rynek. Kapitałony (Miziołek, 1998; 1999) also has a grand influence on the development of knowledge on investment funds, devoting himself in particular to the development of this market segment. The measurement of the effectiveness of the discussed funds itself is referred to in her 
publication by A. Zamojska (2012). In addition, the authors of the present publication itself have, in recent time, made an attempt to evaluate the effectiveness of the Polish national investment fund market in the years 1997-2015 (Mentel, Brożyna, Kompa, \& Szetela, 2016) (Mentel \& Horvathova, 2016).

Analysing the world market, in turn, the forerunners in this regard were I. Friend, F. E. Brown, E. S. Herman and D. Vickers (1964), who had described the analysis of results of a hundred and fifty investment funds existing on the market of the United States of America in the years 1953-1959. The papers already considered fundamental and devoted to the results of investment funds include articles by J. L. Treynor (1965), W. F. Sharpe (1966) and M. Jensen (1968), which had great influence due to the mode of construction of measures aimed at evaluating investment fund results. A great influence, in the context of the development of studies focused on investment funds, was also exercised by the works of I. Friend, M. Blume and J. Crockett (1970), T. Kim (1978), E. C. Chang and W. G. Lewellen (1984), R. D. Henriksson (1984) and J. D. Jackson and S. E. Skomp (1985).

\section{THE MEASURE THE EFFECTIVENESS OF OPEN INVESTMENT FUNDS INVESTING}

Open-ended investment funds play a very important role in the market economy, due to the fact that they influence the effectiveness of results of various financial instruments. One of the reasons for which individual investors purchase units (or shares), is the anticipation of profitable investments that the fund managers can attain. Clients of joint investment institutions look for such funds that have chances of achieving higher returns as compared to safer investments, e. g. bank deposits or treasury securities (Jamróz, 2013).

In a time of financial crisis, the question of the effectiveness of open-ended investment funds as the most popular common investing institutions asserts itself. An evaluation of the effectiveness of fifteen selected funds spanning stock, bonds, the financial market and balanced investment funds operating without interruption in the period between January 1st, 2000 and June 30th, 2015, on the Polish market, was carried out. The study of the effectiveness of the funds was carried out spanning selectivity with the use of popular indicators.

The operating results of investment funds are often measured using their mean rate of return $\left(R_{p}\right)$ over the period of holding of a given investment. It needs to be remembered, however, that the measure of results of the funds considering just the achieved rate of return constitutes an incomplete analysis, with presented high return rates of funds being very enticing for new clients, however, the achieved historic results are no guarantee of achievement of similar returns in the future. In course of the evaluation of a fund's results, one should particularly consider the scale and pace of the fund's growth, the mode of implementation of its investment policy, and the moment and rules of valuation of its assets, while also considering the fact of the existence of inflation (Jamróz, 2011).

The evaluation of the results of operation of investment funds can be subdivided into two groups, with the first being selectivity, and the second - so-called market timing. Selectivity permits one to conduct an analysis of the abilities of the management of the fund assets to skilfully pick companies for the portfolio based on information at hand. Market timing is the ability to foresee phases of stock price rises and falls, and to appropriately react to these market changes by assuring appropriate proportions in the investment portfolio between risky and safe assets, so as to achieve a higher portfolio risk during an upturn, and a lower risk level on declining markets. Selectivity is based in practice on company fundamental analysis, however, with the simultaneous consideration of the results of this analysis against the current market valuation. 
Market timing is based fully on the historic analysis of results of the broad market index (Czekaj \& Woś \& Żarnowski, 2001).

In order to permit a comparison of effectiveness of the management of investment fund portfolios, measures were used adapted to risk. There exist several means of measurement of return rates as compared to the risk borne, with the best known and popular measures of selectivity being the Treynor ratio (Tp), Jensen's alpha $(J)$ and the Sharpe ratio (SP) (Mikulec, 2004).

For a well-diversified portfolio, using the Treynor and Sharpe ratios, one can arrive at similar result ranks. With a weakly diversified portfolio, however, one could achieve a high result according to the Treynor ratio, and a much lower one in case of the Sharpe ratio. Both indicators supply complementary, yet different information, hence it is recommended to use them in concert (Brow \& Reilly, 2001). A development of the Sharpe ratio is Sharpe's alpha $(A S)$, which takes into account investor expectations created by present market results, replaced by the broad market index level. This measure is sensitive to the general market sentiments $^{1}$ (considers investor expectations fuelled by market conditions), thanks to which it is suitable as a tool for comparing investment fund return rates achieved in different periods (Czekaj, Woś \& Zarnowski, 2001).

Jensen's alpha is, in turn, a relative measure (Brow \& Reilly, 2001). The application of Jensen's alpha is particularly recommended for investment funds, the portfolios of which are well diversified. This stems from the fact that the measure of the expected return rate is dependent on the beta of the relevant investment fund (the systematic risk) (Dzielnicki, Gudaszewski, Hnatiuk \& Stefanoff, 2005). This indicator is not used to evaluate bond-based investment funds and the money market. If the return rate of an investment fund is higher than the expected return rate taking into account the risk, then Jensen's alpha has positive values. Positive values describe the level, by which fund results are higher than those expected. If Jensen's alpha in turn should be in the negatives, this means that the investment fund has achieved results below expectations, and that is is found below the SML (Haugen, 1996).

A measure used to evaluate the effectiveness of investment funds is also $M 2$, or the ModiglianiModigliani measure. It measures the rate of return achieved by the relevant fund, based on the total risk of a benchmark M2 assumes that the investment fund portfolio is raised or reduced by risk-free assets using a 'leverage' mechanism of the product of the standard deviation of the investment fund and the standard deviation of the benchmark.

The publication also permitted the determination of additional effectiveness measures, e. g. $S_{p}-$ standard deviation of the rate of return, $E R$ - auxiliary rate of return, $C V_{p}$ - variability coefficient, $R P-$ risk premium, Beta - the beta coefficient, $D R$ - risk diversification, TE - tracking error, IR - information ratio. The multitude of the applied coefficients had the purpose of a fuller analysis and the possibility of later grouping of the funds.

\section{EFFECTIVENESS ANALYSIS}

The effectiveness of an investment fund is determined based on a comparison of its results against results calculated for a benchmark of such a fund (with the benchmark being the main stock index or an investment portfolio specifically designed for this purpose). The fund managers optimise the investment portfolios of the funds they manage based on the benchmark. Hence, the ,,reference portfolio is the basic tool used to study the economic effectiveness of the management of a portfolio of assets in an open-ended

\footnotetext{
${ }^{1}$ This measure, just like Jensen's alpha, is a differentiated measure.
} 
investment fund, (...) the reference portfolio is the benchmark. As investment decisions are reached in name of the fund members by the managing entity, the study of the economic effectiveness of the asset portfolio of a fund should be associated with the study of the skills of the relevant manager"2.

The analysis of effectiveness of investment funds operating on the Polish market was conducted separately for the group of stock-based funds, bond-based funds, for the money market and for balanced funds, due to differences in the structure of the investment portfolios for these fund groups. The research period was subdivided into two subperiods, spanning the years 2000-2006 (before the crisis) and 2007-2013 (during the crisis). Due to limited representation of funds from the money market and balanced funds from the period before the crisis (in particular in the first years of this subperiod), the detailed comparative analysis of the effectiveness of funds before and after the crisis was conducted with respect to stock-based and bond-based funds, as these were sufficiently broadly represented both before the crisis, as well as during its course.

An additional assumption was the calculation of annual effectiveness measures solely for funds that operated for the full twelve months of a particular year. Each fund type was analysed separately, because each of these used a different investment policy. In relation to this, each of the average fund types was compared against a different reference benchmark, as presented in table 1.

Table 1

Construction of the benchmarks for the individual investment fund markets

\begin{tabular}{|l|l|}
\hline \multicolumn{1}{|c|}{ Market } & \multicolumn{1}{c|}{ Benchmark } \\
\hline Investment funds based on Polish stock & $100 \%$ of the WIG index \\
\hline Investment funds based on Polish bonds & $\begin{array}{l}100 \% \text { of the Polish treasury security market index (Pl. } \\
\text { Indeks Rynku Obligacji Skarbowych, IROS) }\end{array}$ \\
\hline Investment funds of the money market & Average return of 13-week treasury securities \\
\hline Balanced investment funds & $(50 \%)$ of the WIG index, (50\%) of the IROS index \\
\hline
\end{tabular}

Source: Own work based on: Ostrowska, E., \& Merchel, A. (2002). Fundusze inwestycyjne na rynku finansowym - stopy wzrostu i benchmarki, [in:] Rynek kapitałowy - skuteczne inwestowanie, ed. by W. Tarczyński, Published by the University of Szczecin, Szczecin, and Stańczak, K. Klasyfikacje funduszy..., op.

Analysed were fifteen stock-based funds and fifteen debt bond-based investment funds, money market investment funds and balanced investment funds. The calculated effectiveness measures for all the investment funds operating on the Polish market in the described time periods were presented in tables 2-5.

A precise analysis of the results concerning the effectiveness of the investment funds as measured according to the Sharpe ratio, Treynor ratio, Jensen's alpha, Sharpe's alpha, the Modigliani-Modligliani measure and the information indicator, had shown that in most individual cases, the effectiveness of management of fund assets was higher in the years 2000-2006 than during the crisis. It can furthermore be assumed that the reduction in effectiveness in a time of crisis was not statistically significant, of each fund is considered separately. Based on the values of the beta coefficient, it can be determined that in the crisis period, the majority of the compared funds used a more aggressive investment strategy than it did before the crisis. Exceptions to this are the following funds: Pionier FIO subfundusz. Akcji Polskich, PKO FIO subfundusz.

2 Doctoral thesis, Bednarz, J. Alternative investment strategies for trust funds under the conditions of the Polish capital market, under prof. dr hab. J. Węcławski, p. 2001. 
Akiji, PZU FIO Akiji Krakowiak, which in the entire analysed period kept to a rather defensive investment policy. It is also noteworthy that in the crisis period, the majority of funds had a lower risk diversification level (than before the crisis) as measured by DR (save for the Investor Parasol subfundusz. Investor Top 25 Matych Spótek, PZU FIO Akcii subfundusz. PZU Krakowiak, BPH Parasolony BPH subfundusz. Akcij funds), whereby the risk as measured via the $C V p$ was higher for the majority of the analysed investment funds in the crisis years than in the years 2000-2006. It needs to be stressed however, that no statistical significance was found for the differences in the results of the measures of risk and returns for the individual funds in the crisis period and in the preceding period. This was most certainly influenced by the size of the analysis sample, limited by the length of the time series spanning the years 2000-2006 and 2007-20015. In regard to this, in order to increase the numbers in the sample, all funds operating for at least one year in the selected period were included in the analysis, and a joint effectiveness test was conducted for complete fund groups. In table 2 were included summary results for the average values of effectiveness measures for all stock-based investment funds operating in the period before the crisis and during the crisis.

Table 2

Mean effectiveness measure values for all stock-based investment funds operating before the crisis and during the crisis

\begin{tabular}{|l|c|c|c|c|c|c|c|c|c|c|c|c|c|c|}
\hline Measure & $\boldsymbol{R} \boldsymbol{p}$ & $\boldsymbol{S} \boldsymbol{p}$ & $\boldsymbol{E R}$ & $\boldsymbol{C V} \boldsymbol{p}$ & $\boldsymbol{R P}$ & $\boldsymbol{B e t a}$ & $\boldsymbol{D R}$ & $\boldsymbol{J}$ & $\boldsymbol{S P}$ & $\boldsymbol{A S}$ & $\boldsymbol{T} \boldsymbol{p}$ & $\boldsymbol{M} \boldsymbol{T}$ & $\boldsymbol{T E}$ & $\boldsymbol{I R}$ \\
\hline $\begin{array}{l}\text { mean } \\
\text { before } \\
\text { the } \\
\text { crisis }\end{array}$ & 20.17 & 1.59 & 11.12 & 13.66 & 24.46 & .159 & 34.81 & 11.11 & 4.74 & 15.37 & 5.97 & 22.80 & 1.54 & 21.08 \\
\hline $\begin{array}{l}\text { mean } \\
\text { during } \\
\text { the } \\
\text { crisis }\end{array}$ & 23.72 & 2.36 & 14.27 & .50 & 23.72 & .834 & 35.71 & 20.59 & 6.54 & 20.23 & 6.03 & 36.86 & 4.75 & 14.07 \\
\hline $\begin{array}{l}\text { mean } \\
\text { before } \\
\text { the } \\
\text { crisis }\end{array}$ & 1.98 & .16 & 1.13 & 1.49 & 2.40 & .016 & 3.52 & 1.13 & .47 & 1.56 & .59 & 2.31 & .16 & 2.14 \\
\hline $\begin{array}{l}\text { mean } \\
\text { during } \\
\text { the } \\
\text { crisis }\end{array}$ & 1.98 & .20 & 1.23 & .05 & 1.98 & .069 & 3.07 & 1.77 & .54 & 1.74 & .50 & 3.17 & .41 & 1.21 \\
\hline
\end{tabular}

Source: Own calculations.

The conclusions presented in table 2, however, are not unequivocal, with some effectiveness indicators, such as Jensen's alpha, Sharpe's alpha, the Treynor ratio, or the auxiliary indicator show improvement of the effectiveness of stock-based investment funds during the crisis, even though the results are not statistically significant. The Modigliani-Modigliani measure and Sharpe's alpha in turn even indicate an improvement of the effectiveness of stock-based funds. In a time of crisis, a statistically significant improvement of the diversification of fund risk was noted, accompanied by a significant reduction in the relative risk (measured using $C V p$ ) and a significant reduction of the mean risk premium (measured using $R p)$.

In addition, it was tested, which funds are similar concerning the subject effectiveness measures. For this purpose, the Ward method, a hierarchical object grouping method, was used. The selection of the grouping method stems from its high effectiveness in terms of determination of actual groupings. 
Characteristics utilised for the purpose of grouping are mean effectiveness indicator values, with the calculations using the Euclidean distance. The grouping results were presented in fig. 1.

From the dendrogram in fig. 1 one can infer that three groups of stock-based investment funds may be derived, with them having the most closely-related effectiveness indicators in the pre-crisis period:

- first group: Novo Fundusz Inwestycyjny Otwarty subfundusz. Novo Akcji, PZU FIO Parasolowy subfundusz. PZU Akcji, BPH FIO Parasolowy BPH subfundusz. Ak.cji, Investor Parasol FIO subfundusz. Investor Akcji, Skarbiec FIO subfundusz. Skarbiec Ak.cja, Investor Parasol FIO subfundusz. Investor Akecji Dusych Spótek Dywidendowych, Aviva Investors FIO Subfundusz. Aviva Inwestors, Arka BZ WBK FIO subfundusz. Arka Akcji Polskich,

- second group: BPH FIO BPH Subfundusz. Akcji Dynamicznych Spótek,

- third group: Investor Parasol FIO subfundusz Investor Top 25 Matych Spótek, NN Parasol FIO subfundusz. Akcji, Legg Mason Parasol FIO subfundusz. Akcji, UniiFundusze FIO subfundusz Pionier Akcji Polskich, Milenium Fundusz. Inwestycyjny Otwarty subfundusz. Akcji.
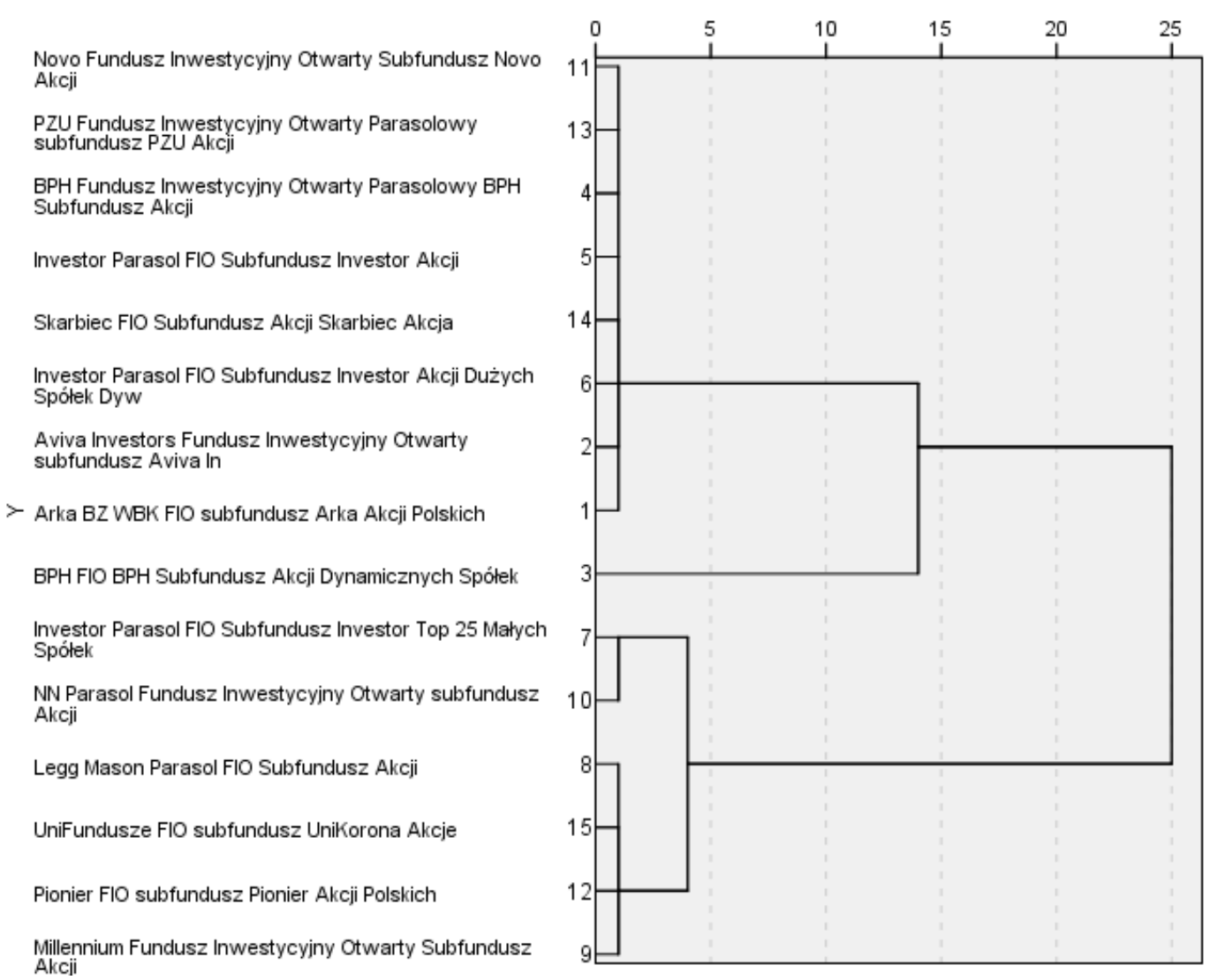

Figure 1. Results of grouping of stock-based investment funds considering asset management effectiveness indicators for the years 2000-2006

Source: Own calculations.

The dendrogram in fig. 2 shows in turn that one could also discern among three groups of stock-based investment funds with most similar effectiveness indicators for the crisis period:

- first group: Investor Parasol FIO subfundusz Investor Top 25 Malych Spótek, Pionier FIO subfundusz Pionier Akcji Polskich, Arka BZ WBK FIO subfundusz. Arka Akcji Polskich, Unii Fundusze FIO subfunusz UniKorona Akcji Polskich, 
- second group: Investor Parasol FIO subfundusz. Investor Akcji, Skarbiec FIO subfundusz. Akcji Skarbiec Akcjia, Legg Mason Parasol FIO subfundusz. Akcji, PZU FIO Parasolony subfundusz PZU Akcji, Investor Parasol FIO subfundusz. Investor Akcji Dusych Spółek. Dywidendowych, BPH FIO subfundusz. Akeji Dynamicznych Spótek, Nova FIO subfundusz. Nova Akcji, BPH FIO Parasolowy BPH subfundusz. Akcji,

- third group: Aviva Investors FIO subfundusz. Aviva Investors Akecji, NN Parasol FIO subfundusz. Akcji, Milenium FIO subfundusz. Ak.cji
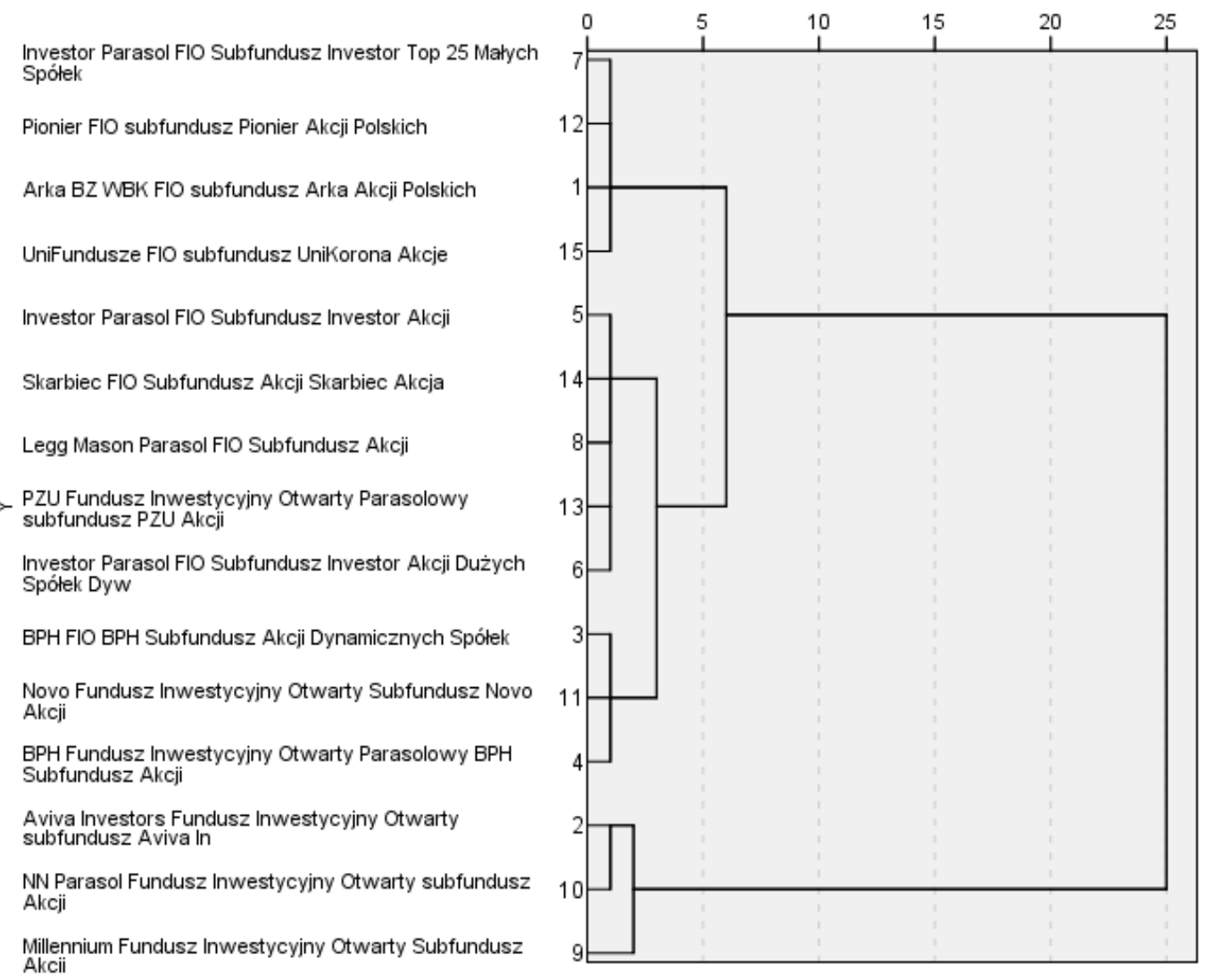

Figure 2. Results of grouping of stock-based investment funds considering asset management effectiveness indicators for the years 2007-2015

Source: Own work

The structures of the emerged fund groups before the crisis (conf. fig. 1) and during the crisis (conf. fig. 2) differ. Noteworthy is in particular the single-component second group (conf. fig. 1), in which only the BPH FIO BPH Subfundusz. Akcji Dynamicznych Spótek investment fund is found, the effectiveness results of which differ from the results of funds in both other groups. It is clearly singled out in this area. If one would take the composition of the fund groups for the years 2000-2006 as a reference, then in the crisis period, a shift has occurred for some investment funds, particularly between groups two and three. The similarities between both these groupings should be assessed as moderate. This is proof of changes in investment strategies of the funds, and, accordingly, in effectiveness results of certain funds in the crisis period as compared to the years 2000-2006.

A thorough analysis of the results concerning the effectiveness of bond-based investment funds, as measured using Sharpe's ratio, Treynor's ratio, Jensen's alpha, Sharpe's alpha, the Modigliani-Modigliani 
measure and the information ratio had shown that for the majority of individual cases, the effectiveness of management of fund assets was higher during the crisis than in the earlier period. An extraordinary exception is the Novo FIO Obligacii Przedsiebiorstw fund, which achieved better effectiveness results before the crisis than during it. The results of the Wilcoxon test for two means did not confirm the differences in the values of the effectiveness indicators for the individual funds as being statistically significant. This, the improvements in effectiveness for bond-based funds during the crisis was not statistically significant, should each fund be considered separately.

An analysis of the beta coefficient values could lead to the conclusion that in the crisis period, some bond-based investment funds had adhered to a more aggressive investment policy than before that crisis. Examples for this may be the BPH FIO Parasolowy BPH subfundusz Obligacji 1, Inwestor Parasol FIO subfundusz Inwestor Obligacji, PZU PIO Papierów Dluzinych Polonez funds. The remaining bond-based funds had reduced their investment policy aggression levels during the crisis. The approach of the bond-based fund managers to the diversification of risk in comparable periods was varied. An increase in the risk diversification level in the crisis period was noticed for the following funds: Skarbiec obligaciji-diuinych papierón wartościonych, Novo FIO Obligacji Przedsiebiorstw, Inventum Parasol FIO subfundusz obligacji, Pionier FIO subfundusz Obligacji Plus, Novo FIO Obligacji Przedsiebiorstw. Other bond-based funds had reduced their risk diversification levels in the crisis period.

Table 3 includes summary results of the average effectiveness measure values for all bond-based funds active in the period before the crisis and during the crisis.

Table 3

Mean effectiveness measure values for all bond-based investment funds operating before the crisis and during the crisis

\begin{tabular}{|l|c|c|c|c|c|c|c|c|c|c|c|c|c|}
\hline Measure & $\boldsymbol{R} \boldsymbol{p}$ & $\boldsymbol{S} \boldsymbol{E}$ & $\boldsymbol{E R}$ & $\boldsymbol{C V} \boldsymbol{p}$ & $\boldsymbol{R P}$ & $\boldsymbol{B e t a}$ & $\boldsymbol{D R}$ & $\boldsymbol{S P}$ & $\boldsymbol{A S}$ & $\boldsymbol{T} \boldsymbol{P}$ & $\boldsymbol{M} 2$ & $\boldsymbol{T E}$ & $\boldsymbol{I R}$ \\
\hline $\begin{array}{l}\text { mean } \\
\text { before } \\
\text { the } \\
\text { crisis }\end{array}$ & 7.79 & 3.35 & -0.94 & 0.66 & 6.97 & 0.663 & 23.96 & -1.33 & -18.6 & -0.02 & 4.34 & 6.16 & -1.11 \\
\hline $\begin{array}{l}\text { mean } \\
\text { during } \\
\text { the } \\
\text { crisis }\end{array}$ & 5.09 & 2.27 & -0.78 & 0.64 & -0.97 & 0.685 & 35.76 & -2.33 & -5.24 & -0.02 & 3.57 & 2.57 & -2.53 \\
\hline $\begin{array}{l}\text { mean } \\
\text { before } \\
\text { the } \\
\text { crisis }\end{array}$ & 6.11 & 1.81 & 3.86 & 0.59 & 3.51 & 0.473 & 7.43 & 2.02 & 21.83 & 1.04 & 11.83 & 4.13 & 5.46 \\
\hline $\begin{array}{l}\text { mean } \\
\text { during } \\
\text { the } \\
\text { crisis }\end{array}$ & 4.82 & 1.53 & 3.65 & 0.54 & 3.98 & 0.442 & 9.55 & 9.56 & 8.41 & 0.20 & 12.52 & 2.72 & 6.65 \\
\hline
\end{tabular}

Source: Own calculations.

A statistically significant improvement of effectiveness in the crisis period was noticed in light of the results of Jensen's alpha and Sharpe's alpha, however, a significant worsening of effectiveness of asset management in the crisis period was noticed for the Modigliani-Modigliani measure. Furthermore, a significant reduction of the translation error TE and information ratio IR was noticed. Bond-based funds in the crisis period statistically significantly improved levels of diversification of the portfolio ( $D R$ measure) 
as compared to the period before the crisis. Characteristic for bond-based investment funds is also the fact of the reduction of the auxiliary rate of return during the crisis period.

In order to test, which bond-based funds are most similar in their asset management effectiveness results, the Ward method using Euclidean distance was again utilised. The characteristics utilised for grouping purposes were, as before, the mean effectiveness measure values. The results of groupings are presented in figures 3 and 4 .
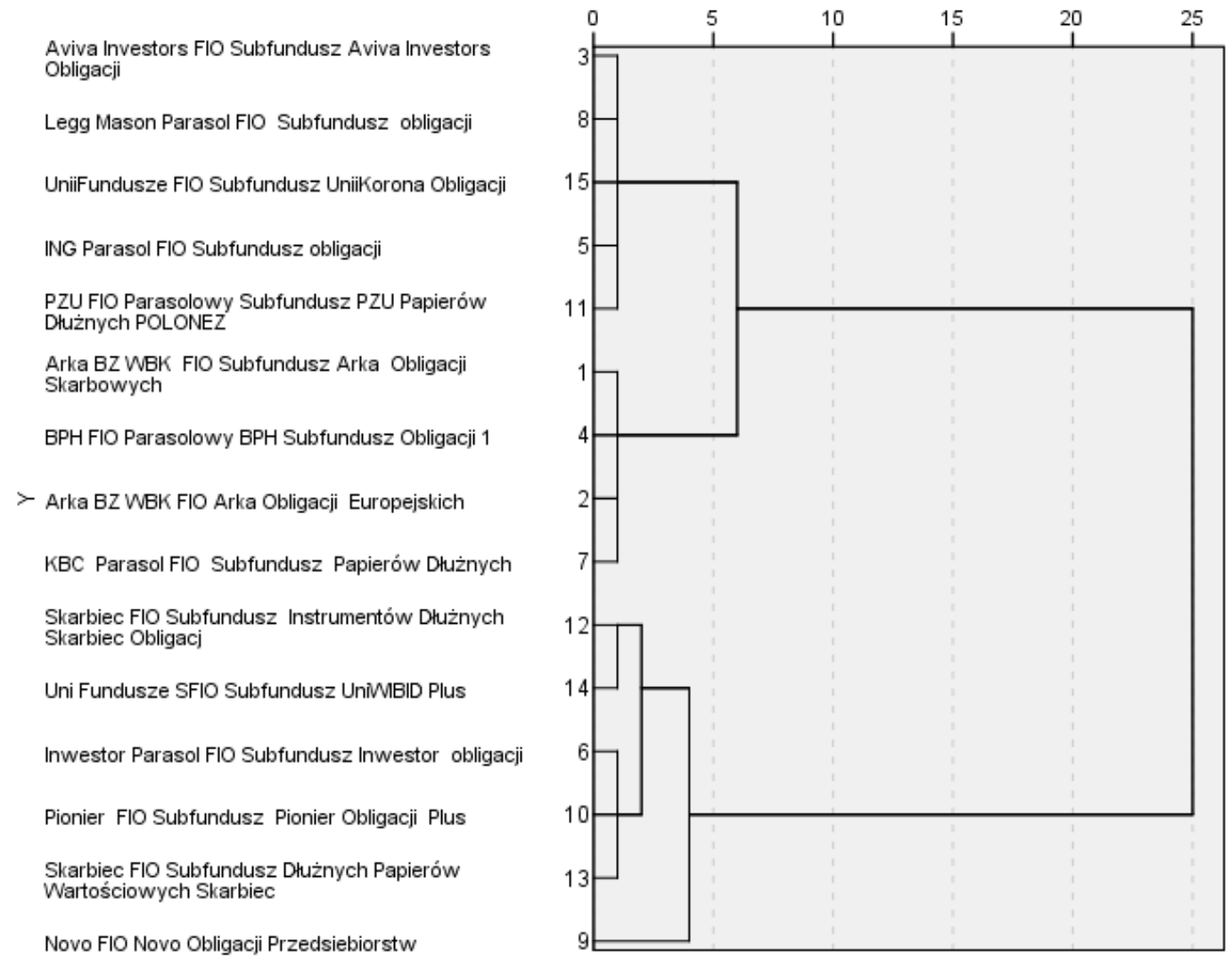

Figure 3. Results of grouping of bond-based investment funds considering asset management effectiveness indicators for the years 2000-2006

Source: Own work

As may be inferred from the dendrogram in fig. 3, three bond-based fund groups with the most similar effectiveness measures in the pre-crisis period may be differentiated between:

- first group: Aviva Investors FIO subfundusz. Aviva Inwestors Obligacii, Legg Mason Parasol FIO subfundusz. obligacji, UniFundusze subfundusz. UniKorona Obligacji, ING Parasol FIO subfundusz obligacii, PZU FIO Parasolowy subfundusz PZU Papierów Dtuzinych Polonez.

- second group: Arka BZ WBK FIO subfundusz. Obligacji skarbowych, BPH FIO Parasolowy subfundusz. Obligacii 1, Arka BZ WBK FIO Arka Obligacji Europejskich, KBC Parasol FIO subfundusz Papierów Dtużnych,

- third group: Skarbiec FIO subfundusz. Instrumentów Dtużych Skarbiec Obligacji, UniFundusze SFIO subfundusz. UniWIBID Plus, Investor Parasol FIO subfundusz Inwestor Obligacii, Pionier FIO subfundusz. Pionier Obligacii Plus, Skarbiec FIO Subfundusz Dtużnych Papierów Wartościowych Skarbiec, Nova FIO Nova Obligacji Proedsiebiorstw. 

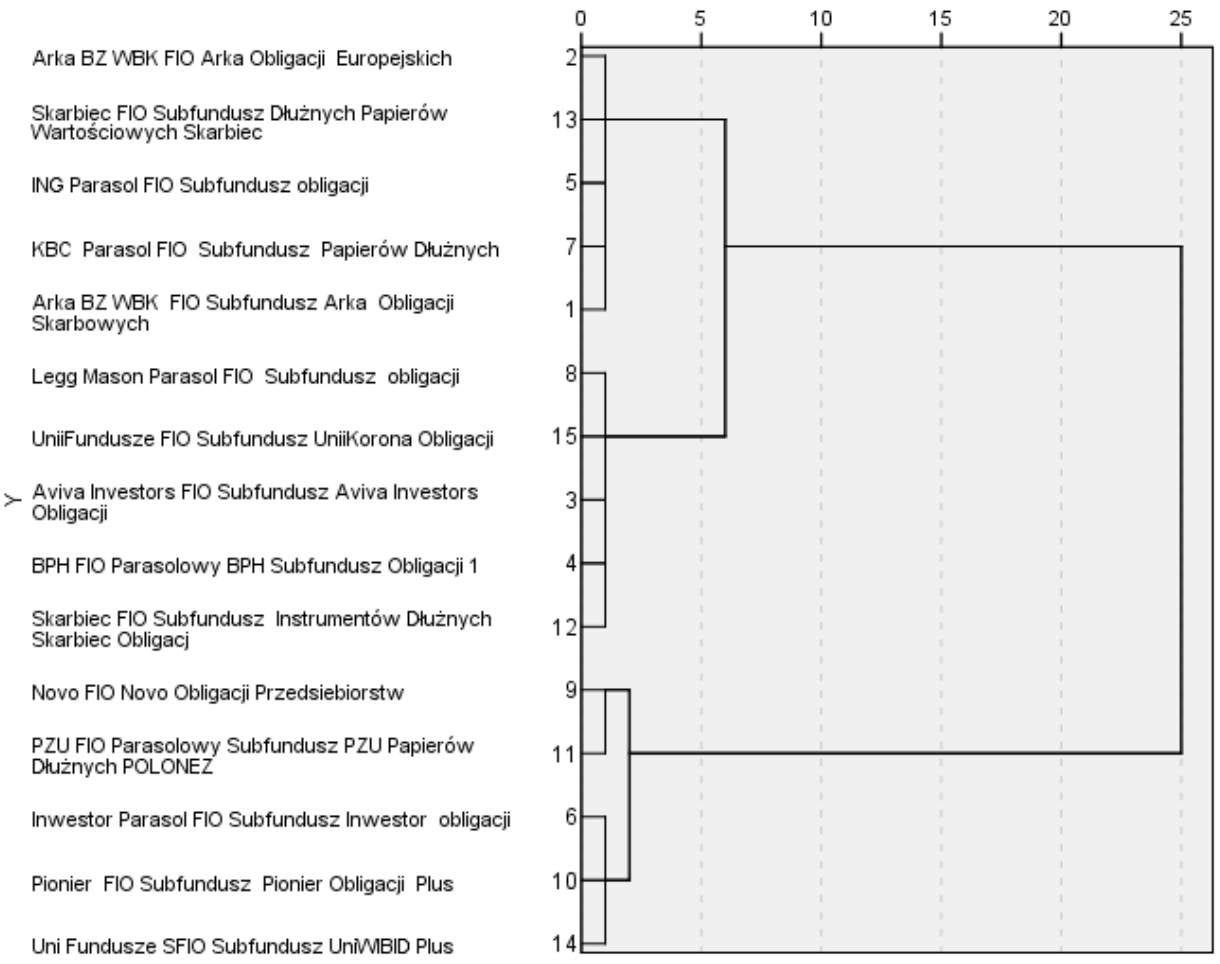

Figure 4. Results of grouping of bond-based investment funds considering asset management effectiveness indicators for the years 2007-2015

Source: Own work

As may be inferred from the dendrogram in fig. 4, three bond-based fund groups with the most similar effectiveness measures in the crisis period may be differentiated between:

- first group: ING Parasol subfundusz Obligacji, KBC Parasol Fundusz Inwestycyjny Otwarty Subfundusz Papierón Dluinych, Arka BZ WBK FIO subfundusz. Arka Obligacji Skarbonych, Skarbiec FIO Subfundusz Instrumentón Dluinych Skarbiec Obligacja,

- second group: Legg Mason Parasol FIO subfundusz obligacji, UniiFundusze FIO subfundusz UniiKorona Obligacji, Aviva Investors FIO subfundusz. Investors Obligacji, BPH FIO Parasolony subfundusz. Obligacji 1, Skarbiec FIO subfundusz. Instrumentów D tużnych Skarbiec Obligacji, Inwestor Parasol FIO subfundusz. Inwestor Obligacji,

- third group: Novo Fundusz. Inwestycyjny Otwarty Subfundusz. Novo Obligacij Przedsiębiorstw, PZU FIO Parasolony subfundusz. PZU Papierón Dlużnych POLONEZ, Pionier FIO subfundusz. Pionier Obligacji Plus, UniFundusze SFIO UniiWIBID Plus.

The structures of the emerged fund groups for the periods before the crisis (conf. fig. 3) and during the crisis (conf. fig. 4) differ to a certain extent. Noticeable is in particular the fund NOVO FIO Obligacii Przedsiebiorstw, which in the years 2000-2006 had to a certain extent made up its own group. The varied make-up of the created groups in both studied periods is proof of a change in the investment strategies of the funds, and, accordingly, the effectiveness results of some funds during the crisis as compared to the years 2000-2006.

Tables 4 and 5 present summary lists of mean effectiveness measure values respectively for money market funds and balanced investment funds. The conducted analysis was, just as before, divided into two subperiods. 
Table 4

Mean effectiveness measure values for all money market investment funds operating before the crisis and during the crisis

\begin{tabular}{|l|l|l|l|l|l|l|l|l|l|l|l|l|l|}
\hline Measure & $\boldsymbol{R} \boldsymbol{P}$ & $\boldsymbol{S p}$ & $\boldsymbol{E R}$ & $\boldsymbol{C V} \boldsymbol{P}$ & $\boldsymbol{R P}$ & $\boldsymbol{B e t a}$ & $\boldsymbol{D R}$ & $\boldsymbol{S P}$ & $\boldsymbol{A S}$ & $\boldsymbol{T} \boldsymbol{P}$ & $\boldsymbol{M} 2$ & $\boldsymbol{T E}$ & $\boldsymbol{I R}$ \\
\hline $\begin{array}{l}\text { mean } \\
\text { before } \\
\text { the } \\
\text { crisis }\end{array}$ & 4.83 & 2.15 & 0.85 & 0.42 & -0.43 & 0.51 & 38.12 & -0.32 & -58.83 & -0.01 & 5.12 & 6.45 & -6.09 \\
\hline $\begin{array}{l}\text { mean } \\
\text { during } \\
\text { the } \\
\text { crisis }\end{array}$ & 3.87 & 1.39 & 0.88 & 0.37 & -2.10 & 0.63 & 40.57 & -2.62 & -36.90 & -0.08 & 3.26 & 6.84 & -7.12 \\
\hline $\begin{array}{l}\text { mean } \\
\text { before } \\
\text { the } \\
\text { crisis }\end{array}$ & 2.02 & 1.26 & 1.40 & 0.15 & 0.93 & 0.38 & 12.38 & 0.54 & 24.81 & 0.04 & 2.23 & 1.48 & 9.34 \\
\hline $\begin{array}{l}\text { mean } \\
\text { during } \\
\text { the } \\
\text { crisis }\end{array}$ & 1.64 & 0.63 & 1.33 & 0.15 & 1.64 & 0.49 & 11.35 & 3.73 & 25.29 & 0.16 & 3.48 & 0.85 & 9.22 \\
\hline
\end{tabular}

Source: Own calculations.

The obtained results are proof that the effectiveness of these investment funds in the crisis period was significantly lower than before the crisis. This is shown by the indicators of Sharpe, Treynor and ModiglianiModigliani. Comparing the results of Sharpe's alpha for both periods, noticeable is a significant improvement of money market funds. For the subject funds, characteristic was also a significant reduction of the risk premium $(R p)$ and reduction of relative risk $(C V p)$. During the crisis, noticed was a statistically significant improvement of diversification of risk for the funds, accompanied by a significant reduction of the standard deviation of the rate of return $\left(S_{p}\right)$, reduction of the risk diversification level $(D R)$ and increase of the auxiliary rate of return (ER) with ain increase in the translation error (TE).

Table 5

Mean effectiveness measure values for all balanced investment funds operating before the crisis and during the crisis

\begin{tabular}{|c|c|c|c|c|c|c|c|c|c|c|c|c|c|c|}
\hline Measure & $R p$ & $S p$ & $E R$ & $C V P$ & $R P$ & Beta & $D R$ & $J$ & $S P$ & $A S$ & $T p$ & M2 & $T E$ & IR \\
\hline $\begin{array}{l}\text { mean } \\
\text { before } \\
\text { the crisis }\end{array}$ & 14.34 & 9.12 & 1.43 & 0.19 & -1.23 & 2.21 & 41.49 & -7.19 & -3.77 & -21.2 & -0.33 & 18.18 & 9.43 & -4.93 \\
\hline \begin{tabular}{|l|} 
mean \\
during \\
the crisis
\end{tabular} & 4.36 & 6.21 & -0.14 & -2.06 & 0.50 & 6.17 & 51.16 & -10.9 & -8.85 & -37.8 & -0.67 & 4.96 & 10.42 & -4.57 \\
\hline \begin{tabular}{|l|} 
mean \\
before \\
the crisis
\end{tabular} & 1.44 & 1.43 & 1.06 & 0.12 & 0.64 & 0.88 & 5.80 & 1.07 & 1.72 & 2.58 & 0.60 & 3.56 & 2.64 & 8.05 \\
\hline \begin{tabular}{|l|} 
mean \\
during \\
the crisis
\end{tabular} & 1.72 & 0.57 & 1.12 & .42 & 1.98 & 1.98 & 7.90 & 2.57 & 2.68 & 9.60 & 1.12 & 9.66 & 5.10 & 6.49 \\
\hline
\end{tabular}

Source: Own calculations. 
Most indicators show that the effectiveness of these funds in the crisis period was significantly lower than before it. This is shown by a comparison of Jensen's alpha, Sharpe's alpha, Treynor's ratio and the Modigliani-Modigliani measure. Comparing Sharpe's ratio in both period, one sees a significant improvement of effectiveness of money market bonds. For the subject funds, characteristic was also a significant reduction of the mean risk premium $(R P)$.

\section{CONCLUSION}

The dynamic development of investment funds had led to a great increase in the capital assets they hold. Globalisation, in eliminating barriers, had led to flow of capital between various countries. The main role in these cash flows is played by various kinds of investment funds. These investment funds had hastened the development of globalisation processes, at the same time adapting to them. They have played a large part in the creation of supranational corporations. They have contributed to an increase in the role of portfolio capital in world markets (Bojańczyk, 2008). The present paper forms a part of research on the effectiveness of investment funds. The study considered a total of several dozens of investment funds, being either stock-based, bond-based, money market and balanced investment funds.

The obtained research results could not fully confirm the hypothesis that in the crisis period, the results of the investment funds are worse than before the crisis. Summary results in this regard for the individual fund groups are unequivocal and depend on the individual group of funds and on selected effectiveness measures. Not rare is the situation, in which one measure would indicate an improvement of effectiveness in the crisis period, with another showing a worsening of fund effectiveness. Nonetheless, most effectiveness measures indicate that it is in particular money-market funds and balanced funds that had significantly reduced their effectiveness in the crisis period. For the remaining fund groups, a conclusion of this kind is not so obvious, as the test results for the individual measures are incoherent.

It needs to be stressed that a higher volume of available data, longer time series could contribute to the improvement of statistical significance of the results. The world investment fund market has been functioning for close to two centuries now, of which the last twenty years have been a period of its very dynamic development. The Polish investment fund market has been in operation for twenty years, of which the last seven have been a time of quite dynamic changes in the net asset values of an ever higher number of funds, which had thus become more and more diversified, both in legal, as well as economic terms. As a result, research on the effectiveness of capital deposits in investment funds in Poland in a time of the financial crisis had become much more real, which does not mean, however, that it had become less complicated to describe and interpret. With the passage of time, as the Polish market is subjected to continued dynamic transformation, some of the conclusions contained in this paper may change, just as the Polish financial market changes (Perez, 2012).

The entire evaluation of the Polish fund market needs to take into account as well that the result to be achieved by a given fund is dependent to a great extent on the skills of its management team. One of the criteria of evaluation of a fund may thus be the stability of this team, which for obvious reasons also facilitates the stability of the fund itself. Good investment funds may thus be recognised by, for instance, the rotation in the management, and this translates to their appropriately good financial results.

A fixed management team, thanks to its experience, is able to usually appropriately interpret market trends and react to them ahead of time. Depending on the fund type, the results are dependent on the fluctuations of prices of securities such as stock and bonds, as well as currency exchange rates. Economic conditions, in which all investment funds operate, are fluent, and accordingly - the profitability of products, in which the funds invest, changes as well. It needs to be remembered, however, that market conditions are 
the same for all investment funds. The issue, whether one of these can gain better results under given conditions than another depends to a great extent specifically on the quality and experience of its team.

In conclusion, the present paper forms an attempt at a comparative analysis of selected investment funds in Poland, and may not be treated as a comprehensive analysis of the entire investment fund market. It needs to be noted that the sector of common investment institutions, dynamically developing in Poland, still analysed only to a limited extent, remains an attractive object of continued empirical study.

\section{REFERENCES}

Bojańczyk, M. (2008). Rola funduszy inwestycyjnych w warunkach globalizacji. SGH, Warszawa.

Bos, T., \& Newbold, P. (1984). An Empirical Investigation of the Possibility of Stochastic Systematic Risk in the Market Model. Journal of Business, 57.

Brown, K. C., \& Reilly, F. K. (2001). Analiza inwestycji i zarządzanie portfelem. Polskie Wydawnictwo Ekonomicznne, Warszawa, 2, 399-402.

Chang, E. C., \& Lewellen, W. G. (1984). Market timing and mutual fund investment performance. Journal of Business, 57(1), 57-72.

Czekaj, J., Wos, M., \& Zarnowski, J. (2001). Efektywnosc gieldowego rynku akcji w Polsce. PWN, Warsqawa.

Dzielnicki, A., Gudaszewski, W., Hnatiuk, M., \& Stefanoff, J. (2005). Pomiar wyników działalności inwestycyjnej. Rynek Terminowy, (3), 9-14.

Fabozzi, F. J., \& Francis, J. C. (1979). Mutual fund systematic risk for bull and bear markets: an empirical examination. The Journal of Finance, 34(5), 1243-1250.

Friend, I., Blume, M., \& Crockett, J. (1970). Mutual funds and other institutional investors: a new perspective. McGraw-Hill Companies.

Friend, I., Brown, F. E., Herman, E. S., \& Vickers, D. (1962). A study of mutual funds. US Government Printing Office, Washington, DC.

Haugen, R. A., \& Pająk, S. (1996). Teoria nowoczesnego inwestowania: obszerny podrecznike analizy portfelowej. Wig-Press.

Henriksson, R. D. (1984). Market timing and mutual fund performance: An empirical investigation. Journal of business, 57(1), 73-96.

Jackson, J. D., \& Skomp, S. E. (1985). On the relative performance of registered versus non-registered mutual funds. Southern Economic Journal, 52(2), 392-401.

Jamróz, P. (2011). Parametryczna ocena umiejętności selektywności i wyczucia rynku zarządzających OFI akcji. Zeşyty Naukowe Uniwersytetu Szczecińskiego. Finanse. Rynki finansowe. Ubezpieczenia, 37, 221-231.

Jamróz, P. (2013). Efektywność wybranych FIO rynku akcji w latach 2003-2011. Finanse, Rynki Finansowe, Ubeapieczenia, 63, 193-206.

Jensen, M. C. (1968). The performance of mutual funds in the period 1945-1964. The Journal of finance, 23(2), 389-416.

Khorana, A., Servaes, H., \& Tufano, P. (2005). Explaining the size of the mutual fund industry around the world. Journal of Financial Economics, 78(1), 145-185.

Kim, T. (1978). An assessment of the performance of mutual fund management: 1969-1975. Journal of Financial and Quantitative Analysis, 13(3), 385-406.

Klemkosky, R. C., \& Maness, T. S. (1978). The predictability of real portfolio risk levels. The Journal of Finance, 33(2), 631-639.

Kon, S. J., \& Jen, F. C. (1978). Estimation of time-varying systematic risk and performance for mutual fund portfolios: an application of switching regression. The Journal of Finance, 33(2), 457-475.

Mayo, H. B. (1997). Wstęp do inwestowania, Wyd. KE Liber, Warszawa.

Mentel G., Brożyna J., Kompa K., \& Szetela B. (2016). Macro and Microeconomics Factors of Investment Efficiency of Open Investment Funds in the period of 1997-2015. Transformations in Business \& Economics, 15(3), 39-43.

Mentel, G., \& Horváthová, Z. (2016). Factors of efficiency of open investment funds in 1997-2015. Economics \& Sociology, 9(1), 101. 
Mikulec, A. (2004). Zastosowanie wskaźników rentowności portfela inwestycji do oceny działalności funduszy inwestycyjnych akcji (cz. I). Nasz Rynek Kapitałowy, 6, 82-86.

Miller, T. W., \& Gressis, N. (1980). Nonstationarity and evaluation of mutual fund performance. Journal of Financial and Quantitative Analysis, 15(3), 639-654.

Miziołek, T. (1998). Wkrótce pierwsze fundusze inwestycyjne. Nasz Rynek Kapitałowy, 12.

Miziołek, T. (1999). Dwa oblicza rynku funduszy. Nasz Rynek Kapitatowy, 11.

Ostrowska, E., \& Merchel, A. (2002). Fundusze inwestycyjne na rynku finansowym-stopy zwrotu i bench-marki, red.[in:] W. Tarczyński, Rynek kapitałowy. Skuteczne inwestowanie, Publisher of University of Szrzecin, Szrzecin.

Perez, K. (2012). Fundusze inwestycyjne: rodzaje, zasady funkecjonowania, efektywność. Wolters Kluwer.

Salamaga, M. (2013). Ocena efektywności wybranych strategii inwestowania cyklicznego na polskim rynku kapitałowym w świetle mierników opartych na modelu CAPM. Studia Ekonomiczne, 163, 113-130.

Sharpe, W. F. (1966). Mutual fund performance. The Journal of business, 39(1), 119-138.

Wilmowska, Z., \& Madera, M. (2001). Fundusze inwestycyjne na polskim rynku. Wydawnictwo KIK, Warszawa.

Witkowska, D. (2009). Efektywność wybranych funduszy akcyjnych w latach 2005-2007. Ekonomika i Organizacja Gospodarki Żywnościowej, 74, 39-61.

Zamojska, A. (2012). EfektywnoÊç funduszy inwestycyjnych w Polsce. Studium teoretyczno-empiryçne, Wyd. CH Beck, Warszawa. 